$\mathrm{MD}$

52,3

602

\title{
The influence of managerial myopia on firm strategy
}

\author{
Jason W. Ridge \\ Department of Management, Clemson University, Clemson, \\ South Carolina, USA \\ Dave Kern \\ Department of Management, Northeastern State University, Tahlequah, \\ Oklahoma, USA, and \\ Margaret A. White \\ Department of Management, Spears School of Business, \\ Oklahoma State University, Tulsa, Oklahoma, USA
}

\begin{abstract}
Purpose - The purpose of this paper is to examine the effects of temporal myopia (focussing on the short-term) and spatial myopia (focussing on the current market) on firm strategy. Specifically the paper investigates the effects of temporal and spatial myopia on the persistence and conformity of firm strategy. Additionally, the paper tests how environmental munificence moderates these effects. A secondary purpose of this paper is to develop a replicable method of measurement of temporal and spatial myopia.

Design/methodology/approach - The authors conducted a manual content analysis of letters to shareholders for 100 firms over three years to measure spatial and temporal myopia. After collecting strategy variables and control variables from Compustat, the authors utilize a random-effects panel methodology.

Findings - The results indicate that strategy is influenced by both temporal and spatial myopia. Specifically, temporal myopia creates a focus on the firm's current strategy, leading to a persistent strategy over time and spatial myopia focusses firm decision makers on better known technologies and competitors, leading to conformity to industry strategic profiles. Additionally, the paper tests how environmental munificence influences these relationships. In total, the paper finds that the differing types of managerial myopia have distinct influences on firm outcomes.

Originality/value - This paper makes two important contributions to the literature on managerial myopia. First, the paper investigates the differential effects of both spatial and temporal myopia on firm strategy, topics that have been relatively overlooked in empirical investigations of decision making. Second, the paper develops replicable measures for both temporal and spatial myopia, which have been previously suggested to limit the ability to empirically test the implications of managerial myopia (Laverty, 1996).
\end{abstract}

Keywords Strategy, Decision making, Decision theory

Paper type Research paper

\section{Introduction}

Most competitive dynamics research has focussed on the competitive environment from an economic viewpoint. However, strategy research clearly shows that the strategic actors of a firm are not always economically objective nor rational (e.g. Hitt and Tyler, 1991; Sutcliffe, 1994). While the major concern of executives is the determination and competitive environment ( $\mathrm{Ng}$ et al., 2009). Although the "social reality is shared," there are many differences in perceptions, interpretations, and strategic actions among direct competitors with very similar environments. It is generally agreed that these differences 
among firms in direct competition are caused by the biases of executive decision makers as they perceive, interpret and act upon their own "social reality" (Bukszar, 1999; Hodgkinson, 1997; McNamara et al., 2002; Pansiri, 2005; Schwenk, 1986; Zajac and Bazerman, 1991).

Therefore, the economic approach of competitive dynamics and the behavioral approach of social reality have both influenced research in strategic management. As Chen et al. (2007) state, competitive dynamics "leaves unexplored some critical issues concerning the relationship between competition and the perceptions and opinions of corporate executives and industry stakeholders” (p. 103). Chen (1996) identified three key drivers of competitive actions (specifically interfirm rivalry) as awareness, motivation and capability. This view of what drives firm action suggests that executive awareness of external cues provides information to be acted upon in the adaptation and change of strategic actions (Chen, 1996). In fact, Chen (1996) suggests, "awareness is considered a prerequisite for any move" (p. 110). In the cue approach of competitive actions (Marcel et al., 2011), awareness has been predominantly suggested to be driven through competitor firm characteristics, such as action visibility, firm size (Chen and Miller, 1994), and relative scale (Chen et al., 2007). In other words, this approach suggests that executives in different firms are equally probable to notice competitor actions. While these cues may direct executive attention, this approach fails to consider how the "social realities" of the actors influence both the noticing and processing of information about competitors' actions (Hambrick et al., 1996). We argue, however that the cognitive biases that executives possess will play a role in how firms direct their strategic actions.

Levinthal and March (1993) suggested three such biases or myopias - hubris, temporal, and spatial - that can affect executive's perceptions of the competitive environment. In research efforts, overconfidence/hubris has been subjected to much more examination (e.g. Hiller and Hambrick, 2005; Li and Tang, 2010; Malmendier and Tate, 2005; Mishina et al., 2010; Ng et al., 2009) than temporal or spatial myopias (Miller, 2002). Because managerial biases can lead to a restrictive interpretation/limited awareness of the competitive environment, we focus our study on the less studied myopias of temporal and spatial. This study is rooted in the competitive dynamics literature, and draws on managerial cognition research (Barr et al., 1992; Marcel et al., 2011; Nadkarni and Barr, 2008; Nadkarni and Narayanan, 2007a; Ng et al., 2009) to investigate the connection between myopic cognitive biases and the persistence and conformity of the firm's strategic actions. Specifically, we provide evidence that as a firm's executives become more temporally myopic, long-term planning is diminished and the firm tends to persist in its current strategy rather than proactively changing direction. Additionally, we find that through the narrowing of focus on a firm's immediate industry created by spatial myopia, the firm's strategy tends to conform to industry standards. However, this relationship is influenced by the growth of the industry in which it operates. Through this research we make three direct contributions to strategic management research. First, we address a much discussed but little tested aspect of cognitive bias, managerial myopia. By doing so we are able to provide insight into how limitations of executive awareness in the temporal and spatial sense affect firm strategic action. Second, we provide an example as to the measurement of managerial myopias. Finally, our results show the distinct differences between spatial and temporal myopia in the influencing of firm strategy, providing additional evidence of the explanatory power of differing cognitive biases in the determination of strategic alternatives.

We examine the issues associated with myopia by using a content analysis of letters to shareholders (LTS). We follow this approach for two reasons. First, as Nadkarni and
Influence of managerial myopia

603 
$\mathrm{MD}$

52,3

604
Barr (2008) suggest, strategic decisions based upon the assimilation and interpretation of information occurs within the top management team (Daft and Weick, 1984; Hambrick and Mason, 1984; Lyles and Schwenk, 1992; Nadkarni and Barr, 2008; Thomas et al., 1993). Thus, the cognitive biases displayed by top management decision makers have direct implications for organizational decisions (Nadkarni and Narayanan, 2007b). Second, the results of multiple studies determine that content analyses of firm communications are particularly informative when determining managerial cognitions (Barr, 1998; D’Aveni and MacMillan, 1990; Yadav et al., 2007). In the subsequent sections, we first review and define the concept of managerial myopia and more specifically temporal and spatial myopia; we then discuss the differential impacts of temporal and spatial myopia on firm strategy; and finally, we describe our study using content analysis to determine the effect of temporal and spatial myopia on firm strategy.

\subsection{Managerial myopia}

Managerial myopia is a stable perspective that narrows the set of alternatives considered by decision makers and relies on underlying theories associated with bounded rationality (Simon, 1957) and learning dysfunctions (Argyris and Schon, 1978; Levitt and March, 1988). Accordingly, managerial myopia reflects a narrow view of temporal choices, organizational capabilities, environmental forces, and strategies external to the firm (Levinthal and March, 1993; Levitt, 1960; Miller, 1993; Richard et al., 1993). The lack of awareness inherent in managerial myopia constrains the recognition of future opportunities (e.g. Lant et al., 1992) and how decision makers scan the environment for strategic alternatives. These restrictions may influence levels of exploitation vs exploration, limit risk-taking, and possibly create errors in the strategic decision-making process (Levinthal and March, 1993).

One inherent problem in management is the issue of intertemporal choice, where a decision must be made between a change to current strategy that will allow for current profitability over the short term or a second choice focussing on changes that direct the organization in the long- term, diminishing short-term performance, but strengthening the firm in the long-term (Laverty, 1996). This quandary and the actions taken to solve it are a direct reflection of managerial myopia. Levinthal and March (1993, p. 110) state that one dimension of managerial myopia tends to "sacrifice the long run to the short run." This dimension of managerial myopia, termed temporal myopia, focusses decision makers on the near term, encouraging short-term financial and accounting solutions to current problems rather than an investment in future opportunities (Hayes and Abernathy, 1980; Hrebiniak and Joyce, 1986; Merchant, 1990; Merchant and Bruns, 1986). In firms whose management displays temporal myopia, decisions are made to influence performance in the short term, disregarding resource investments that may create value in the long term.

In addition to myopic views of temporal problems, managerial myopia also influences investment in "different" opportunities. Levinthal and March (1993, p. 101) characterize spatial myopia as "overlooking distant places" and as "the tendency to ignore the larger picture." Spatial myopia encourages managers and firms to focus on current markets and innovations and can be consistent with long-term investments in the firm. Extending from this conceptualization and other work focussing on spatial myopia (Miller, 2002), we define spatial myopia as a lack of awareness or the denial of the utility of technologies, processes, routines, and markets that are not central to the firm. The lack of awareness in spatial myopia is created by cognitive limitations and boundaries within and between 
organizations. This limits the set of alternatives considered for implementation and favors technologies and routines known or familiar to the executive (Miller, 2002). Through the restriction of attention to "distant" opportunities, environmental scanning for strategic alternatives may be limited, new markets may not be explored (i.e. international expansion, acquisitions), technologies being developed in different industries may be overlooked, and even a limited understanding of current competitors may occur. For instance, Gripsrud and Grønhaug (1985) find that managers of retail firms perceive an undersized portion of all the other stores in their markets to be their competitors. Managers tend to perceive stores that are geographically approximate to them as competitors while disregarding others that are literally more distant (geographically) that are direct rivals.

\subsection{The effect of environmental munificence}

Strategic management content and process literatures increasingly emphasize the importance of incorporating environmental context in empirical research (e.g. Covin et al., 2001; Henderson and Mitchell, 1997). In this study, we specifically address businesses in relatively stable, high growth and low growth industries. Industry growth rate is employed in this study as the primary measure of industry for two reasons. The first is that stable growth rates are logically consistent with the hardening of perspectives associated with management myopia (Miller, 1993). The second is the general agreement about the importance of industry growth as an unambiguous indicator of industry attractiveness. Executive perceptions of opportunity and risks are likely to be impacted by the level of munificence in the external environment (e.g. Lumpkin and Dess, 1996; Tang et al., 2010).

The likelihood that managerial biases will harden and evolve into myopia is expected to be greater in firms that reside in relatively stable industries. A consistent pattern of growth reduces the level of environmental uncertainty. Industry growth has been considered a major indicator of environmental conditions in a broad spectrum of organizational, financial, and strategic management literature (Agarwal et al., 2002; Aldrich, 1979; Dess and Beard, 1984; Hofer, 1980; Porter, 1980). It has also been employed as a primary indicator of favorable conditions in task environment studies (Dess and Beard, 1984; Park and Mezias 2005; Wan and Yiu, 2009) and as the central focus of life cycle theory (Beal and Lockamy, 1999; Hambrick et al., 1982; Polli and Cook, 1969). Clearly, industry growth rate represents a relatively unambiguous and easily understood measure of industry attractiveness, profitability, and competitive pressures (McDougall et al., 1994; Porter, 1980) and has been used to represent industry munificence (Dess and Beard, 1984; Karaevli, 2007; Misangyi et al., 2006).

\section{Hypotheses}

\subsection{Temporal myopia and the persistence of strategy}

The current research builds upon previous research in the economics, finance, and accounting literatures (Laverty, 1996). Laverty (2004) directly links the temporal myopia concept to economic short termism, the term employed most frequently in economics. The economic perspective is associated with the accounting model and to short-term pressures exerted on senior executives to produce quarterly and annual results (Laverty, 1996; Loescher, 1984) as well as how pressure exerted through corporate reward systems and the stock options that favor the short term over the long term (Kogut and Kulatilaka, 1994; Merchant and Bruns, 1986). Kaplan (1984, p. 411) asserts that a fundamental weakness of the accounting system leads managers "to
Influence of managerial myopia

605 
$\mathrm{MD}$

52,3

606 increase reported profits while sacrificing the long-term economic health of the firm." As such, an indicator of temporal bias is a heavy emphasis on short-term financial results, short-term financial planning (in deference to vision or long-term strategy), and short-horizon investments.

Firms with decision makers displaying temporal myopia focus on the current period to the exclusion of the long term, limiting long-term economic growth (Cheng et al., 2007) and firm exploration (Levinthal and March, 1993). Through this myopic viewpoint, decision makers are likely to persist in the firm's previous strategy for two interrelated reasons. First, choices of executives differ as they relate to time horizons. For example, Thaler et al. (1997) show that decision makers prepared to wait a long time before evaluating the outcome of a choice find a risky choice more attractive than decision makers who expect to evaluate the outcome soon. Therefore, decision makers displaying temporal myopia will be more concerned with current strategic alternatives and less focussed on the potential of long-term possibilities (Hayes and Abernathy, 1980). As such, temporal myopia excludes consideration of long-term opportunities that are inherently more risky (cf. Benartzi and Thaler, 1995).

Furthermore, a second reason temporal myopia will create persistence in the current strategy is that the returns of previously engaged-in strategies are ordinarily more certain and closer in time than are returns from deviations from previous strategy (e.g. March, 1991). As such, alterations to the firm's current strategy are likely to lead to poorer results in the short-run (Levinthal and March, 1993). This possibility has direct implications for decision makers displaying temporal myopia as they prefer to make incremental, short-term adjustments to their strategy that will enhance the next quarterly earnings report (Hayes and Abernathy, 1980). As such, the risk aversion and emphasis on short-term financial results inherent in temporal myopia provides an impetus to remain persistent in the firm's current strategy:

\section{H1. Temporal myopia is positively associated with strategic persistence.}

There is substantial evidence that the external environment, particularly munificence, influences executive perceptions, decisions, and actions (e.g. Baum and Wally, 2003; Simsek et al., 2007; Tang et al., 2010). In munificent environments, frequently identified with higher rates of growth, firms find it easier to acquire resources (Deeds and Decarolis, 1999; Wan and Yiu 2009), and develop slack resources that are available for investment in emerging markets (Simsek et al., 2007), expansion (Keats and Hitt, 1988), innovation and change in structures (Aragon-Correa and Sharma, 2003). Munificent environments provide executives a wider breadth of options and discretionary resources (Hambrick and Finkelstein, 1987). Moreover, munificent environments tend to encourage decentralized decision making, more open structures and greater proactiveness in organizations (Simsek et al, 2007; Yasai-Ardekani, 1989). The increased number of opportunities and access to resources will encourage some level of change and reduce the impact of temporal myopia on decision making.

In less munificent environments, competition increases, profit margins decline and discretionary resources are limited. More hostile environments are more likely to reinforce more rigid, conservative approaches to strategic change (Finkelstein and Hambrick, 1990), and contribute to more formalized procedures and centralization of strategic decisions (Yasai-Ardekani, 1989). The hostile environment represented by low industry growth will likely reinforce the hardened biases of myopic executives. Their inclination to avoid risk and focus on the short-term will be reinforced by the real 
and perceived constraints of the market place. They will likely increase focus on cost management and efficiency while avoiding risks associated with changes in strategic direction or structure (Porter, 1980; Wan and Yiu 2009). The inertia of temporal myopia will be reinforced as decision-making centralization and formalization increases (Yasai-Ardekani, 1989). Bias will be further hardened and internal initiative reduced. Therefore, we expect that environmental munificence will weaken the relationship between temporal myopia and strategic persistence:

H2. The positive association between temporal myopia and strategic persistence will be weaker in munificent environments.

\subsection{Spatial myopia and strategic conformity}

Research on spatial myopia is relatively scant. Few articles address the concept directly. Fortunately, a number of published articles address focus on existing technologies, domains, markets, customers, and processes as a form of management myopia (e.g. Christensen and Bower, 1996; Miller, 1993; Rosenkopf and Nerkar, 2001) that clearly parallel the near concept (overlooking distant places) in the definition of spatial myopia employed by Levinthal and March (1993) and Miller (2002). Rosenkopf and Nerkar (2001) associate inwardly focussed exploration and commitment to the current domain with myopic behavior that may lead to competency traps (Levinthal and March, 1993) or core rigidities (Leonard-Barton, 1992). Further, Rosenkopf and Nerkar (2001) associate local search with becoming more competent in the current domain - existing technologies, markets, and customers, and existing knowledge (Rosenkopf and Nerkar, 2001; Stuart and Podolny, 1996). This concept is quite similar to the definition of spatial myopia employed in this study.

Spatial myopia is an extreme focus on current markets, technologies, and administrative structures and is consistent with a lack of awareness of opportunities external to the firm (Miller, 2002). Through the lack of awareness or denial of external markets created by spatial myopia, search for other opportunities by organizational decision makers is restricted. As such, spatial myopia impedes the array of strategic alternatives that a firm considers. While decision makers within a firm develop, generate, and expand their own strategic alternatives, other opportunities are discovered through scanning of industries external to the primary focus of the firm (Huber, 1991; Levitt and March, 1988). When spatial myopia restricts the decision maker's search, it influences the types of strategy the firm pursues. This brings the organization into general conformity with current market tendencies. Through the focus on current markets and the lack of awareness of other industry strategies created by spatial myopia, strategies in organizations with decision makers displaying spatial myopia will conform to those of the organization's competitors in the current industry:

H3. Spatial myopia is positively associated with strategic conformity.

Similar to temporal myopia, environmental munificence will influence the degree to which spatial myopia is associated with strategic conformity. As was previously discussed, spatial myopia is associated with strategic conformity due to limited search. However, in munificent environments the greater amount of opportunities and discretion afforded decision makers creates a context in which search outside of the current domain is more likely. For instance, spatial myopia is consistent with a focus on the near space and an emphasis on exploitation (Levinthal and March, 1993).
Influence of managerial myopia

607 
$\mathrm{MD}$

52,3

608
Yet, the increased capital and opportunities within munificent environments provide the ability to explore new, possibly risky options with limited detriment (Palmer and Wiseman, 1999). As such, we expect that as the environment in which a firm operates becomes more munificent, greater discretion is afforded firm decision makers, minimizing the conformity of a firm's strategy:

H4. The positive association between spatial myopia and strategic conformity will be weaker in munificent environments.

\section{Methods}

3.1 Sample

The data was collected from 100 firms representing 11 industries for the years 1998 through 2000. The industries were chosen because of the relative stability within the industries and the presence of multiple large firms (each industry had at least six firms in the sample). Large firms were used to ensure availability of data and to decrease the possible influence of relative size of the firms. Each of the sample firms was listed on a major stock exchange since 1998, had complete publication of LTS, and had achieved sales of $\$ 1$ billion by the end of 2003 (the final year of the strategic persistence measure). All dependent and control variables were collected from Compustat. As such, in entirety, 300 LTS were coded for our independent variables of myopia (100 firms over three years); however, after collection of all other variables, sample size dropped to 218 total observations.

\subsection{Independent variables}

To assess the predictor variables of interest in this study, we relied on previous research that assessed organizational phenomena through content analysis (e.g. Cheng and Chang, 2009; Cho, 2006; Frankwick et al., 1994; Nadkarni and Barr, 2008; Nadkarni and Narayanan, 2007b; Tuggle et al., 2010a). Content analysis of publicly available documents such as LTS has been used in numerous organizational studies (e.g. Barr et al., 1992; Bowman, 1984; Clapham and Schwenk, 1991; Nadkarni and Barr, 2008; Nadkarni and Narayanan, 2007a, b). Prior empirical studies support the usefulness of analyzing LTS to investigate phenomena such as collective strategy frames (Nadkarni and Narayanan, 2007a), managerial cognition and attention (D'Aveni and MacMillan, 1990; Nadkarni and Barr, 2008; Tuggle et al., 2010a, b), and decision-maker mental models and schemas (Barr et al., 1992; Nadkarni and Narayanan, 2007b), among others. The results of these studies find that content analyses of firm communications help us better understand managerial cognitions (Barr, 1998; D'Aveni and MacMillan, 1990; Yadav et al., 2007) and other phenomena (Michalisin, 2001).

To measure managerial myopia we used LTS. Overall, LTS are official statements made by a firm of its strategy that executive decision makers deem important to communicate (Barr et al., 1992; D'Aveni and MacMillan, 1990; Nadkarni and Barr, 2008). Each LTS was analyzed and coded by one author and another coder. Each coder was provided extensive training and a manual for determining each of the constructs. As a pretest, a set of letters was coded to ensure accuracy of coding and to determine any possible issues in the coding of spatial and temporal myopia. Following the coding process, differences between coders on each letter were reconciled and a mutual decision made in the final coding. Inter-coder reliability prior to reconciliation exceeded 90 percent on both spatial and temporal myopia. After determination of the number of statements in each letter that coincide with the myopia constructs, we followed 
previously used logic - greater emphasis toward an area implies greater consideration (e.g. D’Aveni and MacMillan, 1990; Sonpar and Golden-Biddle, 2008; Tuggle et al., 2010a,b). Temporal and spatial myopia were operationalized as the percentage of statements that coincide with temporal and spatial myopia to the total number of statements in the letter.

Based on previous research temporal myopia is measured by the extent to which short-term financial discussions dominate the LTS. Virtually all LTS include a financial results section; however, the degree of emphasis on short-term financial and capital market issues indicates a focus by decision makers on the short-term aspects of corporate management. Financial emphasis tends to focus attention on short-term results in response to capital market pressures and can reflect a short-term bias by decision makers (Cheng et al., 2007; Dunk and Kilgore, 2001; Tyrrall, 1998; Van der Stede, 2000). Capturing the proportion of space committed to short-term financial results and issues in LTS acts as an indicator of the emphasis the top management team places on short-term goals to the exclusion of long-term initiatives (e.g. Cheng et al., 2007; Merchant, 1990; Merchant and Bruns, 1986; Van der Stede, 2000). Accordingly, our measure of temporal myopia is the ratio of the number of statements addressing short-term financial results and issues to the total number of statements in the letter.

To assess spatial myopia the amount and intensity of statements in LTS associated with an internal focus on the firm's business model to the exclusion of other processes and technologies in industries distant to the firm was used. Following the description of spatial myopia in previous work (Levinthal and March, 1993; Miller, 2002) and the definition developed in this paper, a list of key words (and derivatives) that indicate an internal focus and a disregard for external industries was developed for the content analysis. These words were established through a literature review examining myopic views of decision making and were chosen if they indicated an internal focus. The selected words were then evaluated within the context of adjoining sentences and paragraphs to determine whether the initial coding unambiguously identifies the orientation of the statement. After counting the number of spatial statements, the measure was calculated as a ratio of the number of spatial statements to the total number of statements in the letter. A more detailed discussion of the overall measurement process of both temporal and spatial myopia is included in the Appendix.

Our measure of environmental munificence followed Palmer and Wiseman (1999) and was calculated as the gross sales growth of the industry using the four-digit SIC code. As controls, we also included several organizational and industry variables. First, firm size was constructed as the logarithm of the number of employees in the firm. We also included a control for diversification level measured with the entropy calculation (Palepu, 1985): $\sum P_{i a} \ln \left(1 / P_{i a}\right)$ where $P_{i a}$ is the proportion of a firm's sales in business segment $i$. Additionally, many studies discovered a link between executive tenure and firm decision making, strategic choices, and overall performance (Finkelstein and Hambrick, 1990); consequently, we controlled for CEO tenure. We also controlled for prior firm performance by including the firms return on assets in year $t-1$. In addition to firm determinants, we also included environmental complexity, calculated by dividing the combined sales of the four largest firms in (as ranked by sales in Compustat) within each industry by the total sales of that industry where the industry is defined by the four-digit SIC code (Palmer and Wiseman, 1999).
Influence of managerial myopia

609 
$\mathrm{MD}$

52,3

610

\subsection{Dependent variables}

We followed Finkelstein and Hambrick (1990) to construct our measures of strategic conformity and persistence. The indicators included are controllable by top management, are important strategic choices in our sample, and each is an indicator of a distinct aspect of a firm's strategy. The indicators used were, plant and equipment newness (net plant and equipment/gross plant and equipment) which indicates basic resource allocations, overhead efficiency (selling, general, and administrative expense/ sales) which addresses a firm's expense structure, debt to equity (total debt/equity) which is a measure of financial leverage, and inventory levels (inventories/sales) which indicate production cycle time and working capital management (Finkelstein and Hambrick, 1990). As such, the assessment of these indicators allows the testing of an organizations strategy on multiple aspects and provides an opportunity to establish the effects of managerial myopia on an array of strategic resource allocations of an organization, rather than a unidimensional view of strategy.

Strategic persistence indicates the extent to which a firm's strategy remains stable over time. The measure of persistence was constructed in three steps. First, the firm's five-year (for $t-1$ through $t+3$ ) variance for each strategic indicator was calculated. Next, variance scores for each indicator were standardized by industry and multiplied by minus one to bring the measures in line with the concept of persistence. Finally, each of the standardized indicators was summed to yield an overall measure of strategic persistence (Finkelstein and Hambrick, 1990).

Strategic conformity is the degree to which a firm's strategy is equivalent to the average strategic profile of industry competitors. The strategic indicators making up the strategic persistence measure are similarly used in the conformity measure. This measure was constructed in three steps following Finkelstein and Hambrick (1990). First, each strategic indicator was standardized by industry; next the absolute difference between a firm's score on a strategic indicator and the average score for all firms in the industry was calculated and multiplied by minus one to bring the measure in line with conformity. Finally, each of these indicators was summed to create the strategic conformity measure.

\section{Analysis and results}

We employed a random-effects panel methodology to analyze the data. When $n$ (number of cross-sections) is large and $t$ (number of observations per firm) is small, fixed effects do not consistently estimate the model and random effects are preferred. The results of a Hausman (1978) specification test indicated that random effects models were appropriate. Additionally, a Breusch-Pagan test indicated the presence of heteroskedasticity; as such, White's standard errors were included to account for the problem (White, 1980). Before creating the interaction terms, each of the variables were centered to reduce the potential problem of multicollinearity (West and Aiken, 1991). Following data collection, the total number of records with complete data was 218 because of the underreporting of certain strategic variables. Table I provides descriptive statistics and correlations, while Table II provides results of our hypothesis testing. In each of our models, $R^{2}$ 's are between 0.14 and 0.19 , similar to other recent content analysis studies on attention and cognition (Marcel et al, 2011; Tuggle et al., 2010a, b). Models 1, 2, and 3 in Table II provide the control model and the results for $H 1$ and $H 2$ on strategic persistence. In Model 2 of Table II, the effect of temporal myopia is positive and significant. These results support $H 1$, which predicted that the level of temporal myopia would have a positive relationship with strategic persistence, 


\begin{tabular}{|c|c|c|c|c|c|c|c|c|c|c|c|c|c|}
\hline & Variables & Mean & $\mathrm{SD}$ & 1 & 2 & 3 & 4 & 5 & 7 & 8 & 9 & 10 & \\
\hline 1 & Strategic conformity & -7.77 & 11.43 & & & & & & & & & & myopia \\
\hline 2 & Strategic persistence & 0.03 & 2.15 & -0.02 & & & & & & & & & \\
\hline 3 & Spatial myopia & 0.27 & 0.15 & 0.21 & 0.01 & & & & & & & & \\
\hline 4 & Temporal myopia & 0.15 & 0.12 & -0.09 & 0.24 & -0.16 & & & & & & & \\
\hline 5 & CEO tenure & 9.53 & 10.14 & 0.06 & -0.06 & -0.07 & 0.12 & & & & & & 611 \\
\hline 6 & Prior firm performance & 0.06 & 0.10 & 0.04 & 0.22 & 0.05 & 0.03 & 0.02 & & & & & \\
\hline 7 & Diversification & 0.44 & 0.49 & -0.14 & 0.04 & -0.18 & 0.03 & 0.15 & 0.05 & & & & \\
\hline 8 & Firm size & 2.77 & 1.37 & 0.10 & 0.18 & 0.12 & -0.09 & -0.18 & 0.12 & 0.06 & & & \\
\hline 9 & Environmental munificence & 1.20 & 0.18 & 0.02 & -0.05 & 0.14 & 0.12 & 0.16 & 0.04 & 0.06 & -0.18 & & \\
\hline 10 & Environmental complexity & 0.52 & 0.15 & 0.11 & 0.04 & -0.09 & -0.03 & -0.05 & -0.13 & -0.12 & 0.08 & -0.29 & \\
\hline \multicolumn{13}{|c|}{ Note: ${ }^{\text {a }}$ All correlations $>0.11$ are significant at the $p<0.05$} & correlation matrix ${ }^{\mathrm{a}}$ \\
\hline
\end{tabular}

suggesting that temporal myopia is associated with greater persistence in strategic resource allocations over time. These results suggest that through focussing on short-term actions, management minimizes the amount of change in which the firm engages. Simply put, temporal myopia emphasizes current strategy, leading to more persistence in strategic resource allocations. The results for $\mathrm{H} 2$ are provided in Model 3. The coefficient for the interaction term of temporal myopia and munificence is not significant, providing no support for $\mathrm{H} 2$.

Models 4, 5, and 6 provide the control model and the results for $H 3$ and $H 4$ on strategic conformity. Model 5 of Table II provides results consistent with $H 3$. The coefficient for spatial myopia shows a positive and significant relationship with strategic conformity, indicating that the strategies of firms with greater spatial myopia conform to the general tendency of the industry. This suggests that firms with decision makers displaying spatial myopia mimic strategies of firms that are known to the executives. This results that has implications for the ability of firms to adapt their strategic resource allocations or to deviate from current strategic norms. In Model 6 the coefficient for the interaction term of spatial myopia and munificence is negative and significant, providing support for $H 4$. In munificent environments, firms with decision makers displaying spatial myopia employ strategies that conform less to the central tendencies of the industry. To test the robustness of our results, we also modeled their effects by entering each of the myopia variables individually into the models. This provided evidence consistent with the above reported findings.

\section{Discussion and conclusions}

The foregoing results provide some evidence of how a myopic "shared reality" within a firm may influence the strategic actions pursued by the firm. This is particularly important for understanding competitive dynamics in an industry because not all executives are aware of similar "cues" in the environment or perceive similar cues the same. Executives have their own lenses and biases through which they become aware of and act upon events in the competitive environment. Therefore to truly understand the intricacies of competitive dynamics and firm strategic action the myopic tendencies of the executives that are charged with surveying the environment must be considered. Overall, our findings suggest that to consider competitive dynamics simply from the aspects of environmental or firm characteristics dismisses the influence of executives' awareness and information processing of environmental "realities." 
MD

52,3

612

Table II.

Results of random-effects analysis of the effect of managerial myopia on firm strategy ${ }^{\mathrm{a}}$
कृ

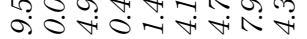

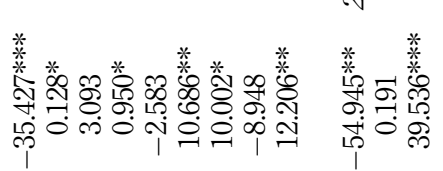

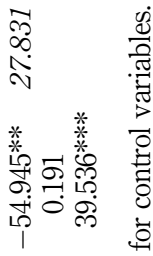

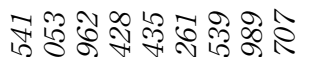

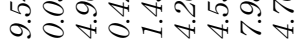

葷

तें

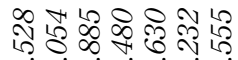

a)

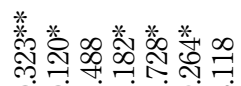

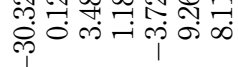

ते 군

nionionionion

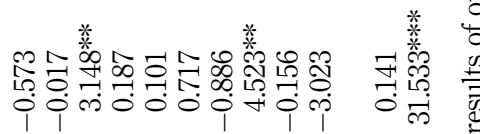

సี่ సิ

i.

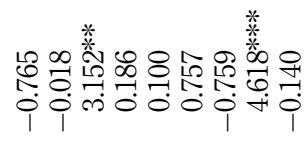

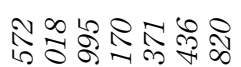

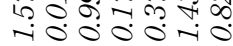

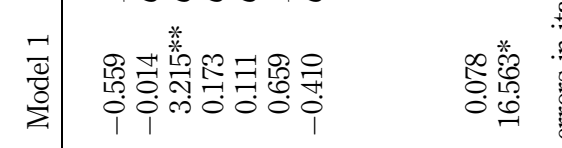

管

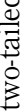

䓠

จ จ



点

F

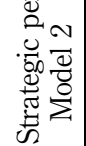

$\frac{20}{2}$

* *

离

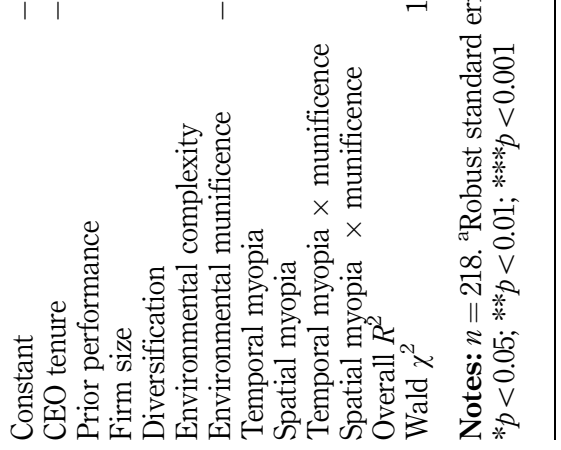


Our findings suggest that there is a distinction between the effects of temporal and spatial myopia on firm strategy. Each of the biases display discrete implications for organizational strategic alternatives. Specifically, we find that due to limitations on the distance in which organizations search, spatial myopia tends to lead an organization to strategically conform to the central tendencies of the current industry in which it competes. This tendency is somewhat due to the isomorphic tendencies of firms doing what they observe (DiMaggio and Powell, 1983), and since spatially myopic executives tend to omit distant search, strategic alternatives similar to firms within their industry is emphasized.

In addition to the strategic outcomes of spatial myopia, our results provide evidence for the persistence of strategy if indications of temporal myopia are present. The focus on the near term displayed by temporal myopia discourages long-term investments and favors incremental changes and persistence in the firm's current strategy. These findings have substantial practical importance in the increasingly turbulent and dynamic industries in which firms now compete (D'Aveni and MacMillan, 1990). In firms in which the "shared realities" tend toward being temporally and spatially myopic, the adjustment of firm strategies may be limited.

Our findings additionally explicate the implications of spatial myopia in munificent industries. We find that in munificent industries, spatial myopia is less associated with strategic conformity. This suggests that the increased capital and opportunities within high growth industries provides the ability to explore new options with limited detriment, creating a context in which there is less restriction of search and decision makers are more apt to adopt strategies from distant markets that do not necessarily conform to their current industry's tendencies. Again, from a practical standpoint, the industry conditions in which a firm competes have implications for firm strategic action. When the firm competes in a high growth industry, the amount of resources and options that are available tend to minimize the limitations of search associated with spatial myopia.

When considering the results of this study, some important limitations warrant discussion. First, our sample was restricted to large firms, and our findings therefore may not be generalizable to all firms in an industry. Second, consistent with prior research, we used a combined index of firm strategy. While this approach allows us to assess how managerial myopias influence a firm's overall resource allocations, it does limit the ability to further understand the effects myopia may have on individual aspects of a firm's strategy. However, we used this measure of firm strategy to remain consistent with the majority of work in the area of strategic change, persistence, and conformity (i.e. Finkelstein and Hambrick, 1990; Zhang and Rajagopalan, 2004; 2010; Zhang, 2006).

While this study sheds light on the implications of managerial myopia to firm strategy, it also left a couple of interesting puzzles and possible extensions for the future. First, the results in this paper could be built upon by beginning to address more specific actions in which firms may engage. For instance, acquisitions and divestitures are risky decisions that have long-term implications for firm strategy. Due to this, it is possible that if a firm's decision makers are temporally myopic, opportunities for acquisition may be overlooked for a more secure short-term return. Not only may temporal myopia affect the acquisition activities due to the long-term implications, but spatially myopic decision makers may be laggards in acquisition because they wait until the strategic tendencies of the industry have changed. This may lead to acquisition of "leftovers." In addition, the spatially myopic firm may focus only on firms in the near
Influence of managerial myopia

613 
$\mathrm{MD}$

52,3

614

space and thus minimize the possibility of engaging in unrelated diversification. This is an area that deserves further exploration. This study opens the possibility that spatial and temporal myopia deserve the attention and research effort that we have seen in the third myopia - overconfidence/hubris.

Beyond possible outcomes of managerial myopia it may also be interesting to expand upon this paper by identifying some of the antecedents of managerial myopia. Laverty (1996) provides an initial theoretical discussion of possible antecedents to temporal myopia; however, certain firm or environmental characteristics may play a role in the development of spatial myopia as well. In addition, the antecedents and outcomes to the awareness-motivation-capability perspective in competitive dynamics (Chen 1996) could provide a guide for a myriad of potential interesting questions about myopia.

In conclusion, to the best of our knowledge, this study is the first to investigate directly, through content analysis, both temporal and spatial myopia and their influence on firm strategy. By doing so, we contribute to the already vast and informative research in competitive dynamics. We provide evidence as to how managerial bias can minimize a firm's awareness to moves external to the firm. As researchers and managers, we need to explore further how the myopias of executives in both the length of time and the breadth of search influence the competitiveness of their firms within the environment.

\section{References}

Agarwal, R., Sarkar, M. and Echambadi, R. (2002), "The conditioning effect of time on firm survival: an industry life cycle approach", Academy of Management Journal, Vol. 45 No. 5 , pp. 971-994.

Aldrich, H.E. (1979), Organizations and Environments, Prentice-Hall, Englewood Cliffs, NJ.

Aragon-Correa, J.A. and Sharma, S. (2003), "A contingent resource-based view of proactive corporate environmental strategy", The Academy of Management Review, Vol. 28 No. 1, pp. 71-88.

Argyris, C. and Schon, D.A. (1978), Organizational Learning: A Theory of Action Perspective, Addison-Wesley Publishing Company, Reading, MA.

Arndt, M. Bigelow, B. (2000), "Presenting structural innovation in an institutional environment: hospitals' use of impression management”, Administrative Science Quarterly, Vol. 45 No. 3, pp. 494-522.

Barr, P.S. (1998), "Adapting to unfamiliar environmental events: a look at the evolution of interpretation and its role in strategic change”, Organization Science, Vol. 9 No. 6, pp. 644-669.

Barr, P.S., Stimpert, J.L. and Huff, A.S. (1992), "Cognitive change, strategic action, and organizational renewal”, Strategic Management Journal, Vol. 13 No. S1, pp. 15-36.

Baum, J. and Wally, S. (2003), "Strategic decision speed and firm performance", Strategic Management Journal, Vol. 24 No. 11, pp. 1107-1129.

Beal, R.M. and Lockamy, A. III (1999), "Quality differentiation for competitive advantage: a contingency approach", European Journal of Innovation Management, Vol. 2 No. 2, pp. 71-81.

Benartzi, S. and Thaler, R.H. (1995), "Myopic loss aversion and the equity premium puzzle", The Quarterly Journal of Economics, Vol. 110 No. 1, pp. 73-92.

Bowman, E.H. (1984), "Content analysis of annual reports for corporate strategy and risk", Interfaces, Vol. 14 No. 1, pp. 61-71.

Bukszar, E. (1999), "Strategic bias: the impact of cognitive biases on strategy", Canadian Journal of Administrative Sciences, Vol. 16 No. 2, pp. 105-117. 
Chen, M. and Miller, D. (1994), "Competitive attack, retaliation and performance: an expectancyvalence framework", Strategic Management Journal, Vol. 15 No. 2, pp. 85-102.

Chen, M.J. (1996), "Competitor analysis and interfirm rivalry: toward a theoretical integration", Academy of Management Review, Vol. 21 No. 1, pp. 100-134.

Chen, M.J., Su, K.H. and Tsai, W. (2007), "Competitive tension: the awareness-motivationcapability perspective”, The Academy of Management Journal, Vol. 50 No. 1, pp. 101-118.

Cheng, M., Subramanyam, K.R. and Zhang, Y. (2007), "Earnings guidance and managerial myopia”, Working paper.

Cheng, S.L. and Chang, H.C. (2009), "Performance implications of cognitive complexity: an empirical study of cognitive strategic groups in semiconductor industry", Journal of Business Research, Vol. 62 No. 12, pp. 1311-1320.

Cho, T.S. (2006), "The effects of executive turnover on top management team's environmental scanning behavior after an environmental change", Journal of Business Research, Vol. 59 No. 10, pp. 1142-1150.

Christensen, C.M. and Bower, J.L. (1996), "Customer power, strategic investment, and the failure of leading firms”, Strategic Management Journal, Vol. 17 No. 3, pp. 197-218.

Clapham, S.E. and Schwenk, C.R. (1991), "Self-serving attributions, managerial cognition, and company performance”, Strategic Management Journal, Vol. 12 No. 3, pp. 219-229.

Covin, J.G., Slevin, D.P. and Heeley, M.B. (2001), "Strategic decision making in an intuitive vs. technocratic mode: structural and environmental considerations", Journal of Business Research, Vol. 52 No. 1, pp. 51-67.

Daft, R.L. and Weick, K.E. (1984), "Toward a model of organizations as interpretation systems", Academy of Management Review, Vol. 9 No. 2, pp. 284-295.

D'Aveni, R.A. and MacMillan, I.C. (1990), "Crisis and the content of managerial communications: a study of the focus of attention of top managers in surviving and failing firms", Administrative Science Quarterly, Vol. 35 No. 4, pp. 634-657.

Deeds, D.L. and Decarolis, D.M. (1999), "The impact of stocks and flows of organizational knowledge on firm performance: an empirical investigation of the biotechnology industry", Strategic Management Journal, Vol. 20 No. 10, pp. 953-968.

Dess, G.G. and Beard, D.W. (1984), "Dimensions of organizational task environments", Administrative Science Quarterly, Vol. 29 No. 1, pp. $52-73$.

DiMaggio, P.J. and Powell, W.W. (1983), "The iron cage revisited-institutional isomorphism and collective rationality in organizational fields", American Sociological Review, Vol. 48 No. 2, pp. 147-160.

Dunk, A.S. and Kilgore, A. (2001), "Reliance on R\&D partnerships: the influence of short-term R\&D bias and the nature of competition", The British Accounting Review, Vol. 33 No. 4, pp. 507-522.

Finkelstein, S. and Hambrick, D.C. (1990), "Top-management-team tenure and organizational outcomes: the moderating role of managerial discretion”, Administrative Science Quarterly, Vol. 35 No. 3, pp. 484-503.

Frankwick, G.L., Walker, B.A. and Ward, J.C. (1994), "Belief structures in conflict: mapping a strategic marketing decision”, Journal of Business Research, Vol. 31 No. 2, pp. 183-195.

Gripsrud, G. and Grønhaug, K. (1985), "Structure and strategy in grocery retailing: a sociometric approach", The Journal of Industrial Economics, Vol. 33 No. 3, pp. 339-347.

Hambrick, D. and Finkelstein, S. (1987), "Managerial discretion: a bridge between polar views of organizations", Research in Organizational Behavior, JAI Press, Greenwich, CT, Vol. 9 pp. 369-406.

Hambrick, D.C. and Mason, P.A. (1984), "Upper echelons: the organization as a reflection of its top managers", Academy of Management Review, Vol. 9 No. 2, pp. 193-206.
Influence of

managerial myopia

615 
$\mathrm{MD}$

52,3

616

Hambrick, D.C., MacMillan, I.C. and Day, D.L. (1982), "Strategic attributes and performance in the BCG matrix - A PIMS-based analysis of industrial product businesses", Academy of Management Journal, Vol. 25 No. 3, pp. 510-531.

Hambrick, D.C., Cho, T.S. and Chen, M.J. (1996), "The influence of top management team heterogeneity on firms' competitive moves", Administrative Science Quarterly, Vol. 41 No. 4, pp. 659-684.

Hausman, J.A. (1978), "Specification tests in econometrics", Econometrica: Journal of the Econometric Society, Vol. 46 No. 6, pp. 1251-1271.

Hayes, R.H. and Abernathy, W.J. (1980), "Managing our way to economic decline", Harvard Business Review, Vol. 58 No. 4, pp. 64-77.

Henderson, R. and Mitchell, W. (1997), "The interactions of organizational and competitive influences on strategy and performance", Strategic Management Journal, Vol. 18, pp. 5-14.

Hiller, N.J. and Hambrick, D.C. (2005), "Conceptualizing executive hubris: the role of (hyper-) core self-evaluations in strategic decision-making”, Strategic Management Journal, Vol. 26 No. 4, pp. 297-319.

Hitt, M.A. and Tyler, B.B. (1991), "Strategic decision models: integrating different perspectives", Strategic Management Journal, Vol. 12 No. 5, pp. 327-351.

Hodgkinson, G.P. (1997), "Cognitive inertia in a turbulent market: the case of UK residential estate agents", Journal of Management Studies, Vol. 34 No. 6, pp. 921-945.

Hofer, C.W. (1980), “Turnaround strategies”, Journal of Business Strategy, Vol. 1 No. 1, pp. 19-31.

Hrebiniak, L.G. and Joyce, W.F. (1986), “The strategic importance of managing myopia”, Sloan Management Review, Vol. 28 No. 1, pp. 5-14.

Huber, G.P. (1991), "Organizational learning: the contributing processes and the literatures", Organization Science, Vol. 2 No. 1, pp. 88-115.

Kaplan, R.S. (1984), "The evolution of management accounting”, Accounting Review, Vol. 59 No. 3, pp. 390-418.

Karaevli, A. (2007), "Performance consequences of new CEO 'Outsiderness': moderating effects of pre-and post-succession contexts", Strategic Management Journal, Vol. 28 No. 7 , pp. 681-706.

Keats, B.W. and Hitt, M.A. (1988), "A causal model of linkages among environmental dimensions, macro organizational characteristics, and performance", Academy of Management Journal, Vol. 31 No. 3, pp. 570-598.

Kogut, B. and Kulatilaka, N. (1994), "Options thinking and platform investments: investing in opportunity”, California Management Review, Vol. 36 No. 2, pp. 52-71.

Lant, T.K., Milliken, F.J. and Batra, B. (1992), "The role of managerial learning and interpretation in strategic persistence and reorientation: an empirical exploration", Strategic Management Journal, Vol. 13 No. 8, pp. 585-608.

Laverty, K.J. (1996), "Economic 'short-termism': the debate, the unresolved issues, and the implications for management practice and research", Academy of Management Review, Vol. 21 No. 3, pp. 825-860.

Laverty, K.J. (2004), "Managerial myopia or systemic short-termism?: The importance of managerial systems in valuing the long term", Management Decision, Vol. 42 No. 8, pp. 949-962.

Leonard-Barton, D. (1992), "Core capabilities and core rigidities: a paradox in managing new product development”, Strategic Management Journal, Vol. 13 No. S1, pp. 111-125.

Levinthal, D.A. and March, J.G. (1993), “The myopia of learning”, Strategic Management Journal, Vol. 14 No. S2, pp. 95-112.

Levitt, B. and March, J.G. (1988), “Organizational learning”, Annual Review of Sociology, Vol. 14 No. 1, pp. 319-340. 
Levitt, T. (1960), “Marketing myopia”, Harvard Business Review, Vol. 38 No. 4, pp. 45-56.

Li, J. and Tang, Y. (2010), "CEO hubris and firm risk taking in China: the moderating role of managerial discretion", Academy of Management Journal, Vol. 53 No. 1, pp. 45-68.

Loescher, S.M. (1984), "Bureaucratic measurement, shuttling stock shares, and shortened time horizons: implications for economic growth", Quarterly Review of Economics and Business, Vol. 24 No. 4, pp. 1-23.

Lumpkin, G.T. and Dess, G.G. (1996), "Clarifying the entrepreneurial orientation construct and linking it to performance", Academy of Management Review, Vol. 21 No. 1, pp. 135-172. , M.A. and Schwenk, C.R. (1992), "Top management, strategy and organizational knowledge structures”, Journal of Management Studies, Vol. 29 No. 2, pp. 155-174.

McDougall, P.P., Covin, J.G., Robinson, R.B. and Herron, L. (1994), "The effects of industry growth and strategic breadth on new venture performance and strategy content", Strategic Management Journal, Vol. 15 No. 7, pp. 537-554.

McNamara, G.M., Luce, R.A. and Tompson, G.H. (2002), "Examining the effect of complexity in strategic group knowledge structures on firm performance", Strategic Management Journal, Vol. 23 No. 2, pp. 153-170.

Malmendier, U. and Tate, G. (2005), “CEO overconfidence and corporate investment”, The Journal of Finance, Vol. 60 No. 6, pp. 2661-2700.

Marcel, J.J., Barr, P.S. and Duhaime, I.M. (2011), "The influence of executive cognition on competitive dynamics”, Strategic Management Journal, Vol. 32 No. 2, pp. 115-138.

March, J.G. (1991), "Exploration and exploitation in organizational learning", Organization Science, Vol. 2 No. 1, pp. 71-87.

Merchant, K.A. (1990), "The effects of financial controls on data manipulation and management myopia”, Accounting, Organizations and Society, Vol. 15 No. 4, pp. 297-313.

Merchant, K.A. and Bruns Jr, W. (1986), "Measurements to cure management myopia”, Business Horizons, Vol. 29 No. 3, pp. 56-64.

Michalisin, M.D. (2001), "Validity of annual report assertions about innovativeness: an empirical investigation", Journal of Business Research, Vol. 53 No. 3, pp. 151-161.

Miller, D. (1993), “The architecture of simplicity”, Academy of Management Review, Vol. 18 No. 1, pp. 116-138.

Miller, K.D. (2002), "Knowledge inventories and managerial myopia", Strategic Management Journal, Vol. 23 No. 8, pp. 689-706.

Misangyi, V.F., Elms, H., Greckhamer, T. and Lepine, J.A. (2006), "A new perspective on a fundamental debate: a multilevel approach to industry, corporate, and business unit effects", Strategic Management Journal, Vol. 27 No. 6, pp. 571-590.

Mishina, Y., Dykes, B.J., Block, E.S. and Pollock, T.G. (2010), "Why good firms do bad things: the effects of high aspirations, high expectations, and prominence on the incidence of corporate illegality", Academy of Management Journal, Vol. 53 No. 4, pp. 701-722.

Nadkarni, S. and Barr, P.S. (2008), "Environmental context, managerial cognition, and strategic action: an integrated view", Strategic Management Journal, Vol. 29 No. 13, pp. 1395-1427.

Nadkarni, S. and Narayanan, V. (2007a), "The evolution of collective strategy frames in high-and low-velocity industries", Organization Science, Vol. 18 No. 4, pp. 688-710.

Nadkarni, S. and Narayanan, V. (2007b), "Strategic schemas, strategic flexibility, and firm performance: the moderating role of industry clockspeed", Strategic Management Journal, Vol. 28 No. 3, pp. 243-270.

Ng, D., Westgren, R. and Sonka, S. (2009), "Competitive blind spots in an institutional field", Strategic Management Journal, Vol. 30 No. 4, pp. 349-369. 
$\mathrm{MD}$

52,3

618
Palepu, K. (1985), "Diversification strategy, profit performance and the entropy measure", Strategic Management Journal, Vol. 6 No. 3, pp. 239-255.

Palmer, T.B. and Wiseman, R.M. (1999), "Decoupling risk taking from income stream uncertainty: a holistic model of risk", Strategic Management Journal, Vol. 20 No. 11, pp. 1037-1062.

Pansiri, J. (2005), "The influence of managers' characteristics and perceptions in strategic alliance practice", Management Decision, Vol. 43 No. 9, pp. 1097-1113.

Park, N.K. and Mezias, J.M. (2005), "Before and after the technology sector crash: the effect of environmental munificence on stock market response to alliances of e-commerce firms", Strategic Management Journal, Vol. 26 No. 11, pp. 987-1007.

Polli, R. and Cook, V. (1969), "Validity of the product life cycle”, Journal of Business, Vol. 42 No. 4, pp. 385-400.

Porter, M.E. (1980), Competitive Strategy: Techniques for Analyzing Industries and Competitors Author, Free press, New York, NY.

Richard, M.D., Womack, J.A. and Allaway, A.W. (1993), "Marketing myopia: an integrated view", Journal of Product \& Brand Management, Vol. 2 No. 3, pp. 49-54.

Rosenkopf, L. and Nerkar, A. (2001), "Beyond local search: boundary-spanning, exploration, and impact in the optical disk industry", Strategic Management Journal, Vol. 22 No. 4, pp. 287-306.

Schwenk, C.H. (1986), "Information, cognitive biases, and commitment to a course of action", Academy of Management Review, Vol. 11 No. 2, pp. 298-310.

Simon, H. (1957), Administrative Behavior, Macmillan, New York, NY.

Simsek, Z., Veiga, J.F. and Lubatkin, M.H. (2007), "The impact of managerial environmental perceptions on corporate entrepreneurship: towards understanding discretionary slack's pivotal role”, Journal of Management Studies, Vol. 44 No. 8, pp. 1398-1424.

Sonpar, K. and Golden-Biddle, K. (2008), "Using content analysis to elaborate adolescent theories of organization”, Organizational Research Methods, Vol. 11 No. 4, pp. 795-814.

Stuart, T.E. and Podolny, J.M. (1996), "Local search and the evolution of technological capabilities", Strategic Management Journal, Vol. 17 No. S1, pp. 21-38.

Sutcliffe, K.M. (1994), "What executives notice: accurate perceptions in top management teams", Academy of Management Journal, Vol. 37 No. 5, pp. 1360-1378.

Tang, Z., Kreiser, P.M., Marino, L. and Weaver, K.M. (2010), "Exploring proactiveness as a moderator in the process of perceiving industrial munificence: a field study of SMEs in four countries", Journal of Small Business Management, Vol. 48 No. 2, pp. 97-115.

Thaler, R., Tversky, A., Kahneman, D. and Schwartz, A. (1997), "The effect of myopia and loss aversion on risk taking: an experimental test", The Quarterly Journal of Economics, Vol. 112 No. 2, pp. 647-661.

Thomas, J.B., Clark, S.M. and Gioia, D.A. (1993), "Strategic sensemaking and organizational performance: linkages among scanning, interpretation, action, and outcomes", Academy of Management Journal, Vol. 36 No. 2, pp. 239-270.

Tsang, E.W.K. (2002), "Self-serving attributions in corporate annual reports: a replicated study", Journal of Management Studies, Vol. 39 No. 1, pp. 51-65.

Tuggle, C.S., Schnatterly, K. and Johnson, R.A. (2010a), "Attention patterns in the boardroom: how board composition and processes affect discussion of entrepreneurial issues", Academy of Management Journal, Vol. 53 No. 3, pp. 550-571.

Tuggle, C.S., Sirmon, D.G., Reutzel, C.R. and Bierman, L. (2010b), "Commanding board of director attention: investigating how organizational performance and CEO duality affect board members' attention to monitoring", Strategic Management Journal, Vol. 31 No. 9, pp. 946-968.

Tyrrall, D. (1998), "Discounted cash flow: rational calculation or psychological crutch?", Management Accounting, Vol. 76 No. 2, pp. 46-48. 
Van der Stede, W.A. (2000), "The relationship between two consequences of budgetary controls: budgetary slack creation and managerial short-term orientation", Accounting, Organizations and Society, Vol. 25 No. 6, pp. 609-622.

Wan, W.P. and Yiu, D.W. (2009), "From crisis to opportunity: environmental jolt, corporate acquisitions, and firm performance", Strategic Management Journal, Vol. 30 No. 7, pp. 791-801.

West, S.G. and Aiken, L.S. (1991), Multiple Regression: Testing and Interpreting Interactions, Sage Publications, Newbury Park, CA.

White, H. (1980), "A heteroskedasticity-consistent covariance matrix estimator and a direct test for heteroskedasticity", Econometrica: Journal of the Econometric Society, Vol. 48 No. 4, pp. 817-838.

Yadav, M.S., Prabhu, J.C. and Chandy, R.K. (2007), "Managing the future: CEO attention and innovation outcomes", Journal of Marketing, Vol. 71 No. 4, pp. 84-101.

Yasai-Ardekani, M. (1989), "Effects of environmental scarcity and munificence on the relationship of context to organizational structure", Academy of Management Journal, Vol. 32 No. 1, pp. 131-156.

Zajac, E.J. and Bazerman, M.H. (1991), "Blind spots in industry and competitor analysis: implications of interfirm (mis)perceptions for strategic decisions", Academy of Management Review, Vol. 16, pp. 37-56.

Zhang, Y. (2006), "The presence of a separate COO/president and its impact on strategic change and CEO dismissal”, Strategic Management Journal, Vol. 27 No. 3, p. 283.

Zhang, Y. and Rajagopalan, N. (2004), "When the known devil is better than an unknown god: an empirical study of the antecedents and consequences of relay CEO succession", Academy of Management Journal, Vol. 47 No. 4, pp. 483-500.

Zhang, Y. and Rajagopalan, N. (2010), "Once an outsider, always an outsider? CEO origin, strategic change, and firm performance”, Strategic Management Journal, Vol. 31 No. 3, pp. 334-346.

\section{Further reading}

Coff, R.W. and Laverty, K.J. (2001), "Roadblocks to competitive advantage: how organizational constraints and individual decision biases hinder investments in strategic assets", The Journal of High Technology Management Research, Vol. 12 No. 1, pp. 1-24.

Das, T.K. (1987), "Strategic planning and individual temporal orientation”, Strategic Management Journal, Vol. 8 No. 2, pp. 203-209.

Das, T. and Teng, B.S. (2001), "Strategic risk behaviour and its temporalities: between risk propensity and decision context", Journal of Management Studies, Vol. 38 No. 4, pp. 515-534.

Datta, D.K., Rajagopalan, N. and Zhang, Y. (2003), "New CEO openness to change and strategic persistence: the moderating role of industry characteristics", British Journal of Management, Vol. 14 No. 2, pp. 101-114.

Fiol, C.M. (1994), "Consensus, diversity, and learning in organizations", Organization Science, Vol. 5 No. 3, pp. 403-420.

Fiske, S. and Taylor, S. (1991), Social Cognition: From Brains to Culture, McGraw-Hill Book Company, New York, NY.

Goll, I. and Rasheed, A. (1997), "Rational decision-making and firm performance: the moderating role of the environment", Strategic Management Journal, Vol. 18 No. 7, pp. 583-591.

Huff, A.S. (1990), Mapping strategic thought, John Wiley and Sons Inc., Hoboken, NJ.

McClelland, P.L., Liang, X. and Barker, V.L. (2010), "CEO commitment to the status quo: replication and extension using content analysis”, Journal of Management, Vol. 36 No. 5, pp. 1251-1277. 
$\mathrm{MD}$

52,3

620
Nath, D. and Newell, S.E. (1998), "Organizational responses to a hypercompetitive environment: a case study of Pepsi Canada”, Journal of Business Research, Vol. 41 No. 1, pp. 41-48.

Osborne, J.D., Stubbart, C.I. and Ramaprasad, A. (2001), "Strategic groups and competitive enactment: a study of dynamic relationships between mental models and performance", Strategic Management Journal, Vol. 22 No. 5, pp. 435-454.

Robinson, K.C. and Phillips McDougall, P. (2001), "Entry barriers and new venture performance: a comparison of universal and contingency approaches", Strategic Management Journal, Vol. 22 Nos 6-7, pp. 659-685.

Schneider, S.C. and Angelmar, R. (1993), “Cognition in organizational analysis: who's minding the store?”, Organization Studies, Vol. 14 No. 3, pp. 347-374.

Segars, A.H. and Kohut, G.F. (2001), "Strategic communication through the world wide web: An empirical model of effectiveness in the CEO's letter to shareholders", Journal of Management Studies, Vol. 38 No. 4, pp. 535-556.

Souder, D. and Bromiley, P. (2012), "Explaining temporal orientation: evidence from the durability of firms' capital investments”, Strategic Management Journal, Vol. 33 No. 5, pp. 550-569.

Souder, D. and Shaver, J.M. (2010), "Constraints and incentives for making long horizon corporate investments”, Strategic Management Journal, Vol. 31 No. 12, pp. 1316-1336.

Wally, S. and Baum, J.R. (1994), "Personal and structural determinants of the pace of strategic decision making", Academy of Management Journal, Vol. 37 No. 4, pp. 932-956.

\section{Appendix. Five-stage process and excerpts from coding instructions}

The content analysis of LTS to identify measures for spatial myopia and temporal myopia involved the following actions, after an extensive evaluation of content analysis articles that provided guidance for the measurement approach these steps were developed following relevant studies (e.g. Arndt and Bigelow, 2000; Barr et al., 1992; D'Aveni and MacMillan, 1990; Tsang, 2002; Tuggle et al., 2010a ,b):

(1) The constructs were clearly defined based on a comprehensive literature review, including an initial set of key words and phrases that was the starting point of the content analysis dictionary/directions. In addition to Levinthal and March's (1993) and Miller's (2002) conceptual articles on management myopia, related concepts (e.g. irrational commitment to the status quo, inertia, Icarus Paradox) were consulted in developing a clear understanding of spatial myopia and temporal myopia.

(2) A sample of over 25 LTS was reviewed to determine both the potential for content analysis and to build the word/phrase dictionaries and instructions. This step was also critical in confirming the importance of determining the context of statements in addition to key words.

(3) Coding instructions and definitions were reviewed by two $\mathrm{PhD}$ candidates with background in strategic management and organizational behavior, but who were not involved in the study. Their input was invaluable in clarifying and simplifying the coding process, including the simplified measure for temporal myopia, and more extensive dictionaries of key words and phrases for spatial myopia.

(4) The coding of the letters was completed by one of the authors and four MBA students with business experience who completed a special topics course taught by an author not involved in the coding. This course included readings in management myopia and related concepts, and an intense review of the concepts and measures included in the study. Training included detailed study of the concepts and coding instructions, review of sample codings, and multiple sessions involving discussion of the concepts and coding. This was followed by a series of three practice codings and subsequent discussion of coding issues and questions. 
(5) At the completion of the training, two coders evaluated each letter in the study sample one of the authors and one of the students. Student coders were assigned specific industries to maximize understanding of any unique terms or concepts in the different industries, which was particularly important in evaluating the context of statements. In the case of any differences in coding, the two coders initially met with a third coder to determine the final coding of the statement in question. In over 99 percent of these situations, the two original coders were able to agree without assistance by the third coder; consequently, the third coder check was not used in subsequent meetings. Initial agreement was 94 percent for the temporal myopia measure and 91 percent for the spatial myopia measurement. This compares favorably to the results of other content analysis studies (e.g. Arndt and Bigelow, 2000; Tsang, 2002).

The following are excerpts from the developed coding instructions to provide additional information.

\section{Definitions and instructions for temporal myopia measures}

The measure for temporal myopia was the extent to which financial statements dominate the letter to shareholders. Virtually all LTS include a financial results section; however, extreme emphasis on financial and capital market issues may indicate a focus of the CEO and the company on the financial aspect of corporate management. Financial emphasis tends to intensify attention on short-term results in response to capital market pressures, and can reflect a built-in, short-term bias. A financial emphasis can crowd out attention to important operational issues, reduce attention to the long-term strategy, and lead to temporal myopia.

The measure for temporal myopia as represented in financial emphasis only includes discussion of financial results. The construct is associated with straight-forward discussions of financial statements that are devoid of strategic orientation or discussion of any type. Only statements that reflect the non-strategic, straight-forward discussion of prior or current financial results or projections should be included. Examples of key words include virtually all items that can be found in income statements, balance sheets, financial results, financial transactions, and stock or equity reports/analysis, including the following: net income, profit, revenue, sales, equity, stocks, shares, gross margin, net margin, earnings per share, market share, and financial (strength/leverage/stability).

Examples of temporal myopia statements as simple reporting of financial results included:

- Instinet's net income in 2001 was $\$ 144.8$ million, down 2.3 percent from the previous year.

- Revenues grew 4.3 percent to $\$ 1.5$ billion, primarily as a result of increased US trading volumes in the first half of 2001.

- During the year, customers executed almost 77 billion US equity shares through Instinet in over 98 million transactions.

- Net transaction fees in US equities were $\$ 994.8$ million, essentially flat compared to 2000.

- Customers also executed almost 8 million transactions in non-US equities in 2001.

- Our share of volume in US exchange-listed stocks increased to 3.1 percent in 2001 from 3.0 percent in 2000.

- We finished the millennium with yet another year of record sales, record profits and record growth.

- Sales grew by $\$ 190.4$ million to $\$ 721.1$ million, a 36 percent increase over the previous year.

- Net income before non-recurring charges was up $\$ 3.3$ million to $\$ 17.8$ million, a 23 percent increase.

- Before non-recurring charges, earnings per share grew by 21 percent to $\$ 0.76$ per share.

\section{Influence of managerial myopia}

621 


\section{Definitions and instructions for spatial myopia measures}

Spatial myopia as measured by a strategic orientation focussed on the current business model: a commitment to technologies, processes, routines, and markets that are central to the existing operations of the firm; emphasis on building and employing core competencies. It is consistent with investment in existing product lines, customer bases, and technology. The willingness to invest in the long-term potential of the existing business model (such as quality programs, research/development, and education/training) separates a focus orientation from a short-term orientation. The emphasis on the current business model discourages exploration and development of new markets and technologies, and strategic alternatives - the greater the focus on the current business model/strategic orientation, the greater the likelihood of spatial myopia.

Consequently, the letters were searched for statements that indicated strategic focus on the current market, current business model, and current strategy. The way we determined that a statement addressed strategic orientation was to focus on key words and the intent of a statement. In order to develop coding instructions, the authors completed an extensive review of LTS from industries not included in this study. From this review, coding instructions, key words, and coding samples were developed. These instructions and coding samples were then reviewed by two strategic management doctoral candidates who provided feedback in refining and simplifying the instructions. The feedback reinforced the importance of addressing the context of the statements, particularly relative to the measure for spatial myopia, and led us to reject a simple word search for the content analysis. The coders continued to build the list of key words and phrases whenever discovering a term that was not included in the initial dictionary or was not clearly an equivalent term, after discussion with other coders.

The coding instructions defined spatial myopia as a focus on "current markets (including customers and industries), technologies, administrative routines, processes, strategies, tactics, and business model." Acquisitions or expansions within existing markets (geographical and industry) were included in the spatial myopia measure. Investments (even long term) in quality improvement, customer service, current product R\&D and infrastructure are fully consistent with a focussed strategic orientation and spatial myopia, and were, therefore, included in the measure. Explorations into new markets, industries, although clearly strategic in nature, are not associated with a spatial myopia, and therefore were excluded in the measure. Heavy emphasis on cost reduction and financial manipulations is associated with a short-term strategy, and may actually undermine the strength of the current strategy and business model, and were omitted from the measure for spatial myopia.

The instructions required that spatial myopia would be identified as statements about the past or future addressing a strategic orientation focussing on current strategies as noted in the definition provided above. Specific instructions augmented the definition:

- Statements involving strategic orientation are often (but not always) found in four sections of LTS. The sections are: the opening paragraph(s); the closing paragraph(s); a section covering recent results and actions specifically identified with a strategic action or orientation; and, a section titled "strategic," or beginning with a sentence that indicates a strategic orientation. The coders were cautioned that this is a general statement - that there is no standard approach in LTS.

- The coding for the spatial myopia measure involves three coordinated steps. Coders were instructed to first determine if a statement references a previous, current, or future strategic action or intent, guided by the following key words: strategy, mission, vision, plan, growth program, initiative, investment (in a strategic action), business model, long term, at the heart of (the business), expand, acquire, build (associated with strategic intent), commitment, create, grow, and drive success.

- Key words and phrases associated with the specific measure for spatial myopia included terms such as evolutionary, continue, extend, focus, quality or customer service improvement, 
current business model, proven approach, investment in our current strategy, continued commitment, refine/reinforce our approach and, facilitates the next stage, and core competence. Extreme focus on the core business or the current strategy can indicate spatial myopia.

- If statement satisfied the first two steps, the coder was instructed to review the context of the statement to ensure that there was no ambiguity in it addressing a focus on the current strategy of the business. If the statement was unclear or ambiguous as to its content, it was to be coded as "ambiguous" or left uncoded. Statements that clearly referred to other statements in a paragraph that were coded as focussed orientation were coded the same. Coders were instructed to consider the intent of the statement within the context of the discussion, rather than a simple review of key words. Specifically, statements that addressed investment in customer service, quality management/improvement, and infrastructure (physical or technology) were coded as a measure of spatial myopia.

Examples of combined phrases for the measure of spatial myopia include (key words or phrases underlined):

- As with our 1991 initiatives, our 1998 efforts are all designed to further Disney's overall corporate mission - to offer quality entertainment that people will seek out.

- Some, like Disney's Animal Kingdom, the new Tomorrowland and the expansion of the Disney Channel, are extensions of established forms of Disney entertainment.

- We are refining our approach with new-found knowledge as we grow, and following a strong, steady path to fulfilling our potential as a leading lifestyle brand (Anne Taylor 1998).

- Everything we are doing today simply builds on the exceptional core equities of the Ann Taylor brand and reinforces our platform for continued growth.

- We want to reiterate, however, that this is an evolutionary, rather than revolutionary, plan.

- The results we are achieving in these new stores are facilitating the next stage of our real estate expansion plans.

\section{Corresponding author}

Dr Jason W. Ridge can be contacted at: jridge@clemson.edu

To purchase reprints of this article please e-mail: reprints@emeraldinsight.com Or visit our web site for further details: www.emeraldinsight.com/reprints 